Article

\title{
Effects of Corn Supplementation into PKC-Urea Treated Rice Straw Basal Diet on Hematological, Biochemical Indices and Serum Mineral Level in Lambs
}

\author{
Osama Anwer Saeed ${ }^{1,2}$, Awis Qurni Sazili ${ }^{1}$, Henny Akit ${ }^{1}$, Abdul Razak Alimon ${ }^{3}$ \\ and Anjas Asmara Samsudin 1,*D \\ 1 Department of Animal Science, Faculty of Agriculture, Universiti Putra Malaysia, Serdang, \\ Selangor 43400, Malaysia; osama_anwr85@yahoo.com (O.A.S.); awis@upm.edu.my (A.Q.S.); \\ henny@upm.edu.my (H.A.) \\ 2 Department of Animal Production, Faculty of Agriculture, University of Anbar, Anbar P.O Box 55431, Iraq \\ 3 Faculty of Animal Science, Universitas Gadjah Mada, Yogjakarta 55281, Indonesia; razalimon@yahoo.co.uk \\ * Correspondence: anjas@upm.edu.my; Tel.: +603-8947-4807
}

Received: 31 July 2019; Accepted: 27 August 2019; Published: 11 October 2019

check for updates

Simple Summary: In Malaysia, livestock farms have used palm kernel cake as the main source of feed for livestock. The low cost and good content of crude protein in palm kernel cake makes it an appropriate food for sheep, but feeding huge amounts of palm kernel cakes (PKC) for a long period may expose them to copper toxicity. This study suggests supplementing a certain amount of corn as a source of energy into PKC basal diets estranged of toxicity to maintain the health status of lambs compared with other treatments, in terms of the hematological and biochemical parameters of lambs.

\begin{abstract}
Twenty-seven Dorper lambs were used to determine the effect of supplementing corn as a source of energy into the palm kernel cake (PKC) urea-treated rice straw basal diet on the blood metabolic profile and metals in lambs. The lambs were randomly allotted to three experimental treatments according to their initial body weight for a 120 day trial. Dietary treatments were: $\mathrm{T} 1$ (control diet) $=75.3 \%$ of $\mathrm{PKC}+0 \%$ corn, $\mathrm{T} 2=70.3 \%$ of $\mathrm{PKC}+5 \%$ corn, and $\mathrm{T} 3=65.3 \%$ of PKC $+10 \%$ corn. The results of this study indicated that copper $(\mathrm{Cu})$, selenium $(\mathrm{Se})$, zinc $(\mathrm{Zn})$, and iron $(\mathrm{Fe})$ concentration intake, retention, and its absorption from the gut and apparent mineral digestibility were highly significant for the levels of corn supplementation. The biochemical and hematological parameters remained within normal levels with the treatments, but the white blood cell, eosinophil count, cholesterol, and low-density lipoprotein cholesterol (LDL) were significantly higher in T3. Treatment 3 significantly increased the concentration of Se and Fe, while Zn was reduced in the blood serum of lambs on day 120. The result shows that the inclusion of corn has no effect on the hematological and biochemical parameters of lambs after incorporating corn into the PKC-based diet at $5 \%$ and $10 \%$.
\end{abstract}

Keywords: hematology; biochemistry; corn; Dorper lambs; palm kernel cake

\section{Introduction}

The high cost of grains for small ruminants due to competition with humans has led to the search for non-conventional sources. Several by-products of oil extraction can be used in animal feed without undesirable effects on the general performance of the animal [1]. Palm kernel cakes (PKC) serve, due to its abundance and availability in Malaysia [2,3], as a cost-effective source of protein 
in formulating rations for ruminants and non-ruminants alike. However, it has been reported that the inclusion of PKC in sheep rations greater than $80 \%$ for a long feeding time is associated with copper $(\mathrm{Cu})$ toxicity, which has a detrimental effect on the liver, especially in crossbreed sheep. The inclusion of $15-35 \%$ level of concentrated PKC is optimal for goat feed. Furthermore, feeding PKC to lambs significantly increases the serum, liver, and meat iron (Fe) concentration (215-251, 49-66, and 14-18 ppm, respectively). It was also found to significantly contribute to the rise in the serum and liver zinc ( $\mathrm{Zn}$ ) concentration (101-130, 35-41, and 26-27 ppm, respectively) [4]. For the determination of metabolic blood profiles, including serum mineral and biochemical parameters, it is necessary to study ruminant metabolism disorders because blood serves as an indicator of the health status of animals and it is normal to assess the cause of an abnormality or malfunction of an animal by examining its blood. Correspondingly, the mineral content and biochemical indicators in the blood of sheep are widely used [5]. Blood contains diagnostically relevant parameters that act as a pathological reflector of the status of animals exposed to toxicants [6]. In reports, there seems to be a paucity of supplementing corn in PKC diets on the status of micro-minerals in the blood of sheep affected by $\mathrm{Cu}$ toxicity, which leads to the deterioration of the blood components of sheep. Moreover, based on the published literature, the proportion of PKC that should be utilized is controversial, mainly because of the mineral and fiber content that alters the replacement levels of PKC in the diets of animals. The combination of corn as a source of energy with different levels of PKC is hypothesized to alleviate the negative effect of feeding PKC to sheep, due to its high copper content. Thus, the present study aims to determine the influence of including corn as a source of energy into the PKC-based diet on the blood metabolic profile and the trace element status in the blood of lambs.

\section{Materials and Methods}

\subsection{Experimental Animals}

Animal experimental procedures were conducted according to the Institutional Committee on Animal Use Ethics (Approval No. R064/2016). A total of 27 lambs (Dorper sheep) with an average live weight of $15 \pm 0.59 \mathrm{~kg}$ were used for this study. The study was conducted at the small ruminant section of the livestock farm in Universiti Putra Malaysia. The lambs were housed in separate pens $(1.20 \mathrm{~m} \times 0.80 \mathrm{~m} \times 0.70 \mathrm{~m})$ equipped with feeders and drinkers. Water was provided ad libitum to the lambs. Ethics approval: It is confirmed that Institutional Animal Care and Use Committee (IACUC), Universiti Putra Malaysia approved this study.

\subsection{Grouping of Animals}

Animals were randomly assigned to three treatments and were fed three levels of corn at $0 \%, 5 \%$, and $10 \%$. Treatment 1 contained $75.3 \%$ PKC and $0 \%$ corn as the control diet, while Treatment 2 contained 70.3\% PKC and 5\% corn, and Treatment 3 included 65.3\% PKC and 10\% corn. Diets were formulated based on the recommendation of Reference [7] to meet the nutritional requirements of growing lambs. The theoretical assumptions for this formulation was based on meeting the body requirements of sheep in terms of protein $(15.1 \%$ ), energy (metabolizable energy $2.8 \mathrm{Mcal} / \mathrm{kg}$ ), and the giving of a high level of PKC to the lambs and watching the physiological changes to the body. These diets were approximately isonitrogenous. Mineral premix was excluded in the diets in order to reduce the amount of $\mathrm{Cu}$, as PKC has a high content of minerals.

\subsection{Collection of Blood Samples}

Blood (10 mL each) collected from the jugular vein was added into both serums of Vacutainer tubes) and ethylene diamine tetra-acetic acid (EDTA) (BD Franklin Lakes, NJ, USA) before feeding the lambs between 09:00 am and 11:00 am at the beginning of the feeding trial $(\mathrm{d} 0)$ and after 40, 80, and 120 days of the experiment. The EDTA tubes $(2 \mathrm{~mL}$ each) were inverted several times to ensure an adequate mixing of the blood with the anticoagulant. After that, the serum was separated by centrifugation 
(10 min) at $2000 \mathrm{~g}$ at $4{ }^{\circ} \mathrm{C}$. The serum was stored at $-20^{\circ} \mathrm{C}$ for biochemical measurements. Blood samples were processed immediately for hemogram analysis to check the general health of the lambs.

\subsection{Hematological and Biochemical Evaluations}

Hematological parameters were evaluated using a hematology analyzer (CELL-DYN 3700 Abbott, Illinois, USA). The biochemical indices such as total glucose, triglycerides, cholesterol, high-density lipoprotein cholesterol (HDL), low-density lipoprotein cholesterol (LDL), and very low-density lipoprotein cholesterol (VLDL) concentrations were measured by the colorimetric method [8]. Aspartate aminotransferase (AST) and alanine aminotransferase (ALT) activities were measured in the Roche Hitachi Diagnostic Modular Analyzer P-800 (Diamond Diagnostic, Massachusetts, USA) by using commercially available diagnostic kits supplied from Roche Diagnostics $\mathrm{GmbH}$ (D-68298, Mannheim, Germany).

\subsection{Mineral Assay}

Samples were digested according to Kolmer et al. [9] method. A total of $0.5 \mathrm{~mL}$ of the serum sample was poured into a digestion flask and $5 \mathrm{~mL}$ of nitric acid $\left(\mathrm{HNO}_{3}\right)$ was added to it. The flask was then placed on a hot plate for 10-15 min until the fumes evaporated and 1-2 $\mathrm{mL}$ of liquid was left in the flask. After allowing the flask to cool down, $2.5 \mathrm{~mL}$ of perchloric acid $\left(\mathrm{HClO}_{4}\right)$ was added to it. The solution in the flask was heated vigorously until the volume again reduced to $1-2 \mathrm{~mL}$. The contents were then filtered and diluted to make up a total volume of $25 \mathrm{~mL}$ by adding deionized water and was stored in plastic bottles for analysis. Each digested and diluted sample was then used for the determination of $\mathrm{Cu}, \mathrm{Fe}, \mathrm{Zn}$, and selenium (Se). All the samples (feed, refusals, feces, and urine) were wetted and ashed in $10 \mathrm{~mL}$ of $\mathrm{HNO}_{3}$ and $5 \mathrm{~mL}$ of $\mathrm{HClO}_{4}$, and analyzed for mineral elements using the same procedure with an increased amount of $\left(\mathrm{HNO}_{3}\right)$ and $\left(\mathrm{HClO}_{4}\right)$. The digested samples $(\mathrm{Cu}, \mathrm{Se}, \mathrm{Zn}$, and Fe) were diluted with deionized triple glass distilled water. The $\mathrm{Cu}, \mathrm{Zn}$, and $\mathrm{Fe}$ concentrations were determined using an inductively coupled plasma atomic emission spectrometer (ICP-OES) (model Optima 8300, Perkin Elmer Inc., Massachusetts, USA) to determine the mineral content. Due to the high selectivity and sensitivity necessary to determine the Se concentration, the Se was measured using an ICP mass spectrometer ELAN Dynamic Reaction Cells (DRC)-e axial field technology (Perkin Elmer SCIEX, Waltham, United Kingdom) using the previous standards of Se.

The calculation of intake, urinary and fecal excretion, apparent absorption, retention, and apparent digestibility were done according to Wang and Fisher [10].

\subsection{Statistical Analysis}

Analyses were made in triplicate and the data obtained were expressed as means, followed by Analyses of Variance (ANOVA) for a completely randomized design using the Statistical Analysis Software (version 9.04). The analysis of variance and Duncan's multiple range tests were used to determine significant differences $(p<0.01$ and 0.05$)$ among treatments. The variances among treatments were valued by using the following model:

$$
Y i j=\mu+\alpha i+e i j
$$

in which Y $i j=$ dependent variable; $\mu=$ overall mean; $\alpha i=$ the fixed effect for supplementation of the level of corn ( 5 and $10 \%)$; and $e \mathrm{ij}=$ experimental error that was assumed to be normally and independently distributed (NID) with $(0, \sigma 2 \mathrm{e})$. 


\section{Results}

\subsection{Minerals Balance}

The treatment diets content of CP was $15.42 \%, 14.88 \%$, and $14.09 \%$, respectively, on a dry matter (DM) basis. The chemical composition and mineral content of the treatment diets are shown in Table 1.

Table 1. Chemical composition and approximate analysis minerals (mg/kg dry matter (DM)) of experimental diets.

\begin{tabular}{cccc}
\hline \multirow{2}{*}{ Parameters } & \multicolumn{3}{c}{ Treatments } \\
\cline { 2 - 4 } & T1 & T2 & T3 \\
\hline DM & 91.78 & 91.66 & 91.55 \\
Ash & 13.80 & 12.72 & 12.74 \\
OM & 86.19 & 87.27 & 87.26 \\
CP & 15.42 & 14.88 & 14.09 \\
EE & 5.3 & 5.1 & 4.33 \\
CF & 26.6 & 24.50 & 20.83 \\
NDF & 62.36 & 60.06 & 55.66 \\
ADF & 45.60 & 40.96 & 37.30 \\
ADL & 6.56 & 6.10 & 5.43 \\
ME MJ/Kg DM & 7.36 & 8.23 & 8.92 \\
\hline Se & 0.36 & 0.34 & 0.29 \\
Cu & 6.16 & 5.96 & 5.80 \\
Zn & 26.25 & 14.65 & 11.28 \\
Fe & 1869.7 & 761.3 & 643.4 \\
\hline
\end{tabular}

T1: $(75.3 \%$ PKC $+0 \%$ corn), T2: (70.3\% PKC $+5 \%$ corn), and T3: $(65.3 \%$ PKC $+10 \%$ corn). Vitamin premix; Vitamin A: 10,000,000 IU; Vitamin E: 70,000 IU; Vitamin D: 1,600,000 IU; DM: dry matter; OM: organic matter; CP: crude protein; EE: ether extract; CF: crude fiber; NDF: neutral detergent fiber; ADF: acid detergent fiber; ADL: acid detergent lignin; and ME: metabolizable energy.

Copper concentration intake and retention, and its absorption from the gut and apparent mineral digestibility, were significantly affected by the supplementation of corn into diets compared with control diets, while there was no effect between T2 and T3 $(p<0.01)$ (Table 2). A significant increase in the concentration of $\mathrm{Cu}$ was recorded in lambs fed $\mathrm{T} 2$ and $\mathrm{T} 3$ in the parameters of the study, while the excretion of $\mathrm{Cu}$ in fecal matter decline was significant $(p<0.01)$ with the inclusion of corn in the dietary treatment. The total excretion of $\mathrm{Cu}$ had no significant difference among the treatment groups, but the amount of $\mathrm{Cu}$ retained increased gradually $(p<0.01)$ in response to $\mathrm{Cu}$ levels in both corn diets.

Table 2. Copper balance by Dorper lambs fed with different levels of corn.

\begin{tabular}{|c|c|c|c|c|c|}
\hline \multirow{2}{*}{ Item } & \multicolumn{5}{|c|}{ Treatments } \\
\hline & T1 & T2 & T3 & SEM & $p$-Value \\
\hline Intake (mg/d) & $5.73^{\mathrm{B}}$ & $7.41^{\mathrm{A}}$ & $7.39^{\mathrm{A}}$ & 0.08 & $* *$ \\
\hline \multicolumn{6}{|l|}{ Excretion $(\mathrm{mg} / \mathrm{d})$} \\
\hline Fecal & $4.19^{\mathrm{A}}$ & $3.64^{\text {B }}$ & $3.60^{\mathrm{B}}$ & 0.09 & ** \\
\hline Urinary & $0.64 \mathrm{AB}$ & $0.36^{\mathrm{B}}$ & $0.90^{\mathrm{A}}$ & 0.09 & $* *$ \\
\hline Total & 3.76 & 3.22 & 3.25 & 0.15 & NS \\
\hline \multicolumn{6}{|l|}{ Apparent absorption } \\
\hline$(\mathrm{mg} / \mathrm{d})$ & $1.84^{\mathrm{B}}$ & $3.76^{\mathrm{A}}$ & $3.78^{\mathrm{A}}$ & 0.08 & $* *$ \\
\hline of intake $\%$ & $28.27^{\text {B }}$ & $48.38^{\mathrm{A}}$ & $48.28^{\mathrm{A}}$ & 0.72 & ** \\
\hline Retention & $06 \mathrm{~B}$ & $10 \mathrm{~A}$ & $11 \mathrm{~A}$ & 008 & $* *$ \\
\hline of intake \% & $34.40^{\mathrm{B}}$ & $54.45^{\mathrm{A}}$ & $53.34 \mathrm{~A}$ & $\begin{array}{l}0.00 \\
0.68\end{array}$ & ** \\
\hline Apparent mineral digestibility (\%) & $28.67^{\text {B }}$ & $48.38^{\mathrm{A}}$ & $48.28^{\mathrm{A}}$ & 0.71 & $* *$ \\
\hline Mineral balance (\%) & $34.08^{B}$ & $54.45^{\mathrm{A}}$ & $53.34 \mathrm{~A}$ & 0.70 & $* *$ \\
\hline
\end{tabular}

T1: (75.3\% PKC + 0\% corn), T2: (70.3\% PKC + 5\% corn), and T3: (65.3\% PKC + 10\% corn). Different capital letters indicate statistically significant differences among the treatment groups $(p<0.01)$. NS: not significant statistically $(p>0.05),{ }^{* *} p<0.01$. 
However, the Se balance during the 120 days of the study showed significant differences among treatments, as seen in Table 3. Significant difference in Se intake was recorded at its highest in T3 $(p<0.001)$, while T2 had the lowest Se intake. The execration of Se in fecal matter and urine was not similar among all treatments, although it tended to be high in T3 lambs $(p<0.001)$. A significant increase in the levels of Se shows apparent absorption, retention, mineral digestibility, and mineral balance $(p<0.01)$ in lambs fed on T3 when compared with T1.

Table 3. Selenium balance by Dorper lambs fed with different levels of corn.

\begin{tabular}{cccccc}
\hline Item & \multicolumn{5}{c}{ Treatments } \\
\cline { 2 - 6 } & T1 & T2 & T3 & SEM & $p$-Value \\
\hline Intake (mg/d) & $0.33^{\mathrm{B}}$ & $0.31^{\mathrm{C}}$ & $0.37^{\mathrm{A}}$ & 0.003 & $* * *$ \\
Excretion (mg/d) & & & & & \\
Fecal & $0.15 \mathrm{a}^{\mathrm{B}}$ & $0.16^{\mathrm{A}}$ & $0.13^{\mathrm{B}}$ & 0.003 & $* * *$ \\
Urinary & $0.522^{\mathrm{A}}$ & $0.035^{\mathrm{B}}$ & $0.012^{\mathrm{B}}$ & 0.105 & $* * *$ \\
Total & $0.18^{\mathrm{A}}$ & $0.14^{\mathrm{B}}$ & $0.12^{\mathrm{B}}$ & 0.009 & $* *$ \\
Apparent absorption & & & & & \\
mg / d & $0.18^{\mathrm{B}}$ & $0.15^{\mathrm{C}}$ & $0.24^{\mathrm{A}}$ & 0.004 & $* * *$ \\
of intake $\%$ & $52.28^{\mathrm{B}}$ & $46.97^{\mathrm{C}}$ & $62.58^{\mathrm{A}}$ & 0.606 & $* * *$ \\
Retention & & & & & \\
mg/d & $0.15^{\mathrm{B}}$ & $0.16^{\mathrm{B}}$ & $0.25^{\mathrm{A}}$ & 0.004 & $* * *$ \\
of intake $\%$ & $43.24^{\mathrm{C}}$ & $50.77^{\mathrm{B}}$ & $65.66^{\mathrm{A}}$ & 0.672 & $* * *$ \\
Apparent mineral digestibility (\%) & $52.88^{\mathrm{B}}$ & $46.97^{\mathrm{C}}$ & $62.58^{\mathrm{A}}$ & 0.591 & $* *$ \\
Mineral balance (\%) & $44.04^{\mathrm{C}}$ & $50.77^{\mathrm{B}}$ & $65.66^{\mathrm{A}}$ & 0.700 & $* *$
\end{tabular}

T1: (75.3\% PKC + 0\% corn), T2: (70.3\% PKC + 5\% corn), and T3: (65.3\% PKC + 10\% corn). Different capital letters indicate statistically significant differences among the treatment groups $(p<0.01$ and $p<0.001)$. NS: not significant statistically $(p>0.05)^{* *} p<0.01$ and ${ }^{* * *} p<0.001$.

The $\mathrm{Zn}$ balance of lambs fed with different levels of corn diets is presented in Table 4 . The lambs fed with corn treatment diets (T2 and T3) had lower $(p<0.001) \mathrm{Zn}$ intake and Zn excretion in feces than those fed on T1. However, excretion of $\mathrm{Zn}$ via urine was not significantly different $(p>0.05)$ between treatment groups. The inclusion of $5 \%$ and $10 \%$ corn into the treatment diets were significantly lower $(p<0.001)$ in the apparent absorption and retention of $\mathrm{Zn}$ in lambs fed with these diets. The apparent mineral digestibility and mineral balance recorded a high percentage $(p<0.001)$ in T2 and T3 until the T1.

Table 4. Zinc balance by Dorper lambs fed with different levels of corn.

\begin{tabular}{cccccc}
\hline Item & \multicolumn{5}{c}{ Treatments } \\
\cline { 2 - 6 } & T1 & T2 & T3 & SEM & $p$-Value \\
\hline Intake $(\mathrm{mg} / \mathrm{d})$ & $24.41^{\mathrm{A}}$ & $13.63^{\mathrm{B}}$ & $14.39^{\mathrm{B}}$ & 0.30 & $* * *$ \\
Excretion $(\mathrm{mg} / \mathrm{d})$ & & & & & \\
Fecal & $13.67^{\mathrm{A}}$ & $7.23^{\mathrm{B}}$ & $5.65^{\mathrm{C}}$ & 0.50 & $* * *$ \\
Urinary & $2.10^{\mathrm{A}}$ & $1.81^{\mathrm{A}}$ & 2.23 & 0.17 & $\mathrm{NS}$ \\
Total & $12.16^{\mathrm{A}}$ & $6.52^{\mathrm{B}}$ & $5.34^{\mathrm{B}}$ & 0.51 & $* * *$ \\
Apparent absorption & & & & & \\
mg/d & $11.52^{\mathrm{A}}$ & $6.39^{\mathrm{C}}$ & $8.73^{\mathrm{B}}$ & 0.20 & $* * *$ \\
of intake $\%$ & $43.55^{\mathrm{B}}$ & $44.35^{\mathrm{B}}$ & $58.31^{\mathrm{A}}$ & 0.62 & $* * *$ \\
Retention & & & & & \\
mg/d & $12.42^{\mathrm{A}}$ & $7.11^{\mathrm{C}}$ & $9.04^{\mathrm{B}}$ & 0.22 & $* * *$ \\
of intake $\%$ & $48.00^{\mathrm{B}}$ & $49.82^{\mathrm{B}}$ & $60.60^{\mathrm{A}}$ & 0.58 & $* * *$ \\
Apparent mineral digestibility (\%) & $43.24^{\mathrm{B}}$ & $44.83^{\mathrm{B}}$ & $58.31^{\mathrm{A}}$ & 0.62 & $* * *$ \\
Mineral balance (\%) & $49.02^{\mathrm{B}}$ & $49.82^{\mathrm{B}}$ & $60.60^{\mathrm{A}}$ & 0.56 & $* * *$ \\
\hline
\end{tabular}

T1: (75.3\% PKC + 0\% corn), T2: (70.3\% PKC + 5\% corn), and T3: (65.3\% PKC + 10\% corn). Different capital letters indicate statistically significant differences among the treatment groups $(p<0.001)$. NS: not significant statistically $(p>0.05)$ and ${ }^{* * *} p<0.001$. 
The concentration of Fe balance among treatments is shown in Table 5. The Fe intake and fecal excretion were highly significant $(p<0.001)$ in T1 compared with other diets. The level of Fe excreted in the urine was also significant $(p<0.001)$ and increased with the inclusion of corn in T2 and T3. However, the apparent digestibility and retention of Fe were significantly different among treatments $(p<0.001)$ with T2 and T3, which had a lower quantity of Fe compared to T1. In the apparent mineral digestibility and mineral balance of $\mathrm{Fe}$, there was a highly significant difference $(p<0.01)$ among treatments, with the highest and lowest observed in the T3 and T2 treatments, respectively.

Table 5. Iron balance by Doper lambs fed with different levels of corn.

\begin{tabular}{cccccc}
\hline Item & \multicolumn{5}{c}{ Treatments } \\
\cline { 2 - 6 } & T1 & T2 & T3 & SEM & $p$-Value \\
\hline Intake (mg/d) & $1739.10^{\mathrm{A}}$ & $708.57^{\mathrm{C}}$ & $820.54^{\mathrm{B}}$ & 25.13 & $* * *$ \\
Excretion (mg/d) & & & & & \\
Fecal & $889.46^{\mathrm{A}}$ & $461.16^{\mathrm{B}}$ & $336.95^{\mathrm{C}}$ & 33.95 & $* * *$ \\
Urinary & $7.01^{\mathrm{B}}$ & $15.45^{\mathrm{B}}$ & $170.14^{\mathrm{A}}$ & 29.78 & $* * *$ \\
Total & $774.36^{\mathrm{A}}$ & $420.64^{\mathrm{B}}$ & $321.78^{\mathrm{B}}$ & 35.99 & $* * *$ \\
Apparent absorption & & & & & \\
mg/d & $855.95^{\mathrm{A}}$ & $271.72^{\mathrm{C}}$ & $476.11^{\mathrm{B}}$ & 17.32 & $* * *$ \\
of intake \% & $47.96^{\mathrm{B}}$ & $35.36^{\mathrm{C}}$ & $56.19^{\mathrm{A}}$ & 0.66 & $* * *$ \\
Retention & & & & & \\
mg/d & $977.03^{\mathrm{A}}$ & $294.29^{\mathrm{C}}$ & $491.64^{\mathrm{B}}$ & 18.48 & $* * *$ \\
of intake \% & $53.54^{\mathrm{B}}$ & $39.05^{\mathrm{C}}$ & $58.17^{\mathrm{A}}$ & 0.65 & $* * *$ \\
Apparent mineral digestibility (\%) & $48.18^{\mathrm{B}}$ & $33.97^{\mathrm{C}}$ & $56.45^{\mathrm{A}}$ & 0.69 & $* *$ \\
Mineral balance (\%) & $54.45^{\mathrm{B}}$ & $38.77^{\mathrm{C}}$ & $58.17^{\mathrm{A}}$ & 0.65 & $* *$ \\
\hline
\end{tabular}

T1: (75.3\% PKC + 0\% corn), T2: (70.3\% PKC + 5\% corn), and T3: (65.3\% PKC + 10\% corn). Different capital letters indicate statistically significant differences among the treatment groups $(p<0.01$ and $p<0.001)$. NS: not significant statistically $(p>0.05)^{* *} p<0.01$ and ${ }^{* * *} p<0.001$.

\subsection{Hematological and Biochemical Parameters}

The data on hematological parameters from blood collected in this experiment are presented in Table 6. The level of white blood cells (WBC) was higher $(p<0.05)$ in T3, while T2 did not differ when compared to T1. No significant variation $(p>0.05)$ in red blood cells $(\mathrm{RBC})$, Hemoglobin $(\mathrm{Hb})$, packed cell volume (PCV), mean corpuscular volume (MCV), mean corpuscular hemoglobin concentration (MCHC), B neutrophils (B Neut), S neutrophils (S Neut), and basophils (Baso) thrombocytes (Thrombo) were detected among the treatment groups. On the contrary, lymphocytes (Lymp), monocytes (Mono), and eosinophils (Eosin) concentrations in lambs fed with the T3 diet was higher when compared with lambs fed with the T1 diet.

Table 6. The effect of PKC-urea treated rice straw supplemented with different levels of corn on the hematological blood parameters in lambs.

\begin{tabular}{cccccc}
\hline \multirow{2}{*}{ Parameters } & \multicolumn{5}{c}{ Treatments } \\
\cline { 2 - 6 } & T1 & T2 & T3 & SEM & $p$-Value \\
\hline $\mathrm{RBC} \times 10^{12} / \mathrm{L}$ & 10.51 & 9.98 & 10.15 & 0.19 & $\mathrm{NS}$ \\
$\mathrm{Hb} \mathrm{g} / \mathrm{L}$ & 104.65 & 103.25 & 103.88 & 1.45 & $\mathrm{NS}$ \\
$\mathrm{PCV} \mathrm{L} / \mathrm{L}$ & 0.293 & 0.292 & 0.286 & 0.004 & $\mathrm{NS}$ \\
$\mathrm{MCV} \mathrm{fL}$ & 28.12 & 29.40 & 28.53 & 0.33 & $\mathrm{NS}$ \\
$\mathrm{MCHC} \mathrm{g} / \mathrm{L}$ & 357.20 & 353.51 & 363.04 & 1.68 & $\mathrm{NS}$ \\
$\mathrm{WBC} \times 10^{9} / \mathrm{L}$ & $7.48^{\mathrm{b}}$ & $7.82^{\mathrm{ab}}$ & $8.81^{\mathrm{a}}$ & 0.22 & $*$ \\
$\mathrm{~B} \mathrm{Neut} \times 10^{9} / \mathrm{L}$ & 0.080 & $0.102^{2}$ & 0.095 & 0.004 & $\mathrm{NS}$ \\
$\mathrm{S} \mathrm{Neut} \times 10^{9} / \mathrm{L}$ & 3.40 & 3.72 & 3.68 & 0.13 & $\mathrm{NS}$ \\
$\mathrm{Lymp} \times 10^{9} / \mathrm{L}$ & $3.399^{\mathrm{b}}$ & $3.398^{\mathrm{b}}$ & $4.101^{\mathrm{a}}$ & 0.12 & $*$ \\
Mono $\times 10^{9} / \mathrm{L}$ & $0.387^{\mathrm{b}}$ & $0.401^{\mathrm{b}}$ & $0.504^{\mathrm{a}}$ & 0.01 & $*$ \\
\hline
\end{tabular}


Table 6. Cont.

\begin{tabular}{cccccc}
\hline \multirow{2}{*}{ Parameters } & \multicolumn{5}{c}{ Treatments } \\
\cline { 2 - 6 } & T1 & T2 & T3 & SEM & $p$-Value \\
\hline Eosin $\times 10^{9} / \mathrm{L}$ & $0.147^{\mathrm{B}}$ & $0.148^{\mathrm{B}}$ & $0.298^{\mathrm{A}}$ & 0.01 & $* * *$ \\
Baso $\times 10^{9} / \mathrm{L}$ & 0.091 & 0.101 & 0.141 & 0.009 & NS \\
Thrombo & 680.07 & 725.12 & 831.29 & 34.85 & NS \\
\hline
\end{tabular}

T1: (75.3\% PKC + 0\% corn), T2: (70.3\% PKC + 5\% corn), and T3: (65.3\% PKC + 10\% corn). Different capital letters indicate statistically significant differences among the treatment groups $(p<0.001)$. Different lowercase letters indicate statistically significant differences among the treatment groups $(p<0.05)$. NS: not significant statistically $(p>0.05)$ ${ }^{*} p<0.05$ and ${ }^{* * *} p<0.001$. PKC = palm kernel cake; RBC = red blood cell; PCV = packed cell volume; $\mathrm{MCV}=$ mean corpuscular volume; $\mathrm{MCHC}=$ mean corpuscular hemoglobin concentration; and WBC = white blood cell.

The serum biochemistry of the Dorper lambs fed with the treatment diets are shown in Table 7. The values obtained were not significantly different $(p>0.05)$ among the three treatment diets fed to the lambs in some of the blood parameters measured. The serum's total cholesterol level showed significant differences $(p<0.05)$ among treatments, which was higher in T3, but did not differ in T2 compared to T1. The highest LDL-cholesterol was recorded in T3, whereas T2 and T1 had the smallest $(p<0.05)$.

Table 7. Effect of PKC-urea treated rice straw supplemented with different levels of corn on the biochemical blood parameters in lambs.

\begin{tabular}{cccccc}
\hline \multirow{2}{*}{ Parameters } & \multicolumn{5}{c}{ Treatments } \\
\cline { 2 - 6 } & T1 & T2 & T3 & SEM & $p$-Value \\
\hline ALT U/L & 15.47 & 12.81 & 11.81 & 0.79 & NS \\
ALP U/L & 151.80 & 163.45 & 152.80 & 8.01 & NS \\
AST U/L & 115.30 & 103.67 & 107.91 & 2.55 & NS \\
Cholesterol, mmol/L & $2.52^{\mathrm{b}}$ & $2.79 \mathrm{ab}$ & $3.13^{\mathrm{a}}$ & 0.10 & $*$ \\
Glucose, mmol/L & 3.22 & 3.40 & 3.47 & 0.10 & $\mathrm{NS}$ \\
Triglyceride, mmol/L & 0.61 & 0.58 & 0.60 & 0.03 & $\mathrm{NS}$ \\
LDL-cholesterol, mmol/L & $0.575^{\mathrm{b}}$ & $0.571^{\mathrm{b}}$ & $0.726^{\mathrm{a}}$ & 0.03 & $*$ \\
HDL-cholesterol, mmol/L & 1.82 & 2.11 & 2.28 & 0.09 & $\mathrm{NS}$ \\
VLDL-cholesterol, mmol/L & 0.22 & 0.21 & 0.26 & 0.01 & $\mathrm{NS}$ \\
\hline
\end{tabular}

T1: (75.3\% PKC + 0\% corn), T2: (70.3\% PKC + 5\% corn), and T3: (65.3\% PKC + 10\% corn). Different lowercase letters indicate statistically significant differences among the treatment groups $(p<0.05)$. NS: not significant statistically $(p>0.05)$ and $* p<0.05$. ALT $=$ alanine transaminase; ALP = alkaline phosphatase; AST $=$ aspartate aminotransferase; $\mathrm{LDL}=$ low density lipoprotein; $\mathrm{HDL}=$ high density lipoprotein; and VLDL = very low density lipoprotein.

\subsection{Minerals of Serum}

The concentration of serum minerals measured at $0,40,80$, and 120 days are shown in Figure 1. Dietary treatments at day 0 did not affect $(p>0.05)$ the level of retention of $\mathrm{Cu}, \mathrm{Se}, \mathrm{Zn}$, and Fe in lambs. There were no effects $(p>0.05)$ of treatments on the concentration of $\mathrm{Cu}, \mathrm{Se}$, and $\mathrm{Zn}$ in blood serum, but for Fe retention, higher retention occurred in lambs fed on $\mathrm{T} 1$ at day 40 . The recorded values were consistent at day 80 of the study and no differences were observed between lambs fed with corn at that time. Exhibiting the same trend, on the $120^{\text {th }}$ day, the data revealed that serum $\mathrm{Cu}$ was not significantly affected $(p>0.05)$ by the treatment. However, the Se level in the blood serum was higher $(p<0.001)$ in lambs fed with T3 than in those fed with only PKC urea-treated rice straw (T1). The serum concentration of $\mathrm{Zn}$ was lower $(p<0.05)$ for T2 and T3 than for the standard diet, while the differences between the two diets tended to small. Serum retention of Fe in lambs were different $(p<0.05)$, and higher Fe serum levels were noticed in lambs fed on the T3 diet, followed the by T2 and T1. 


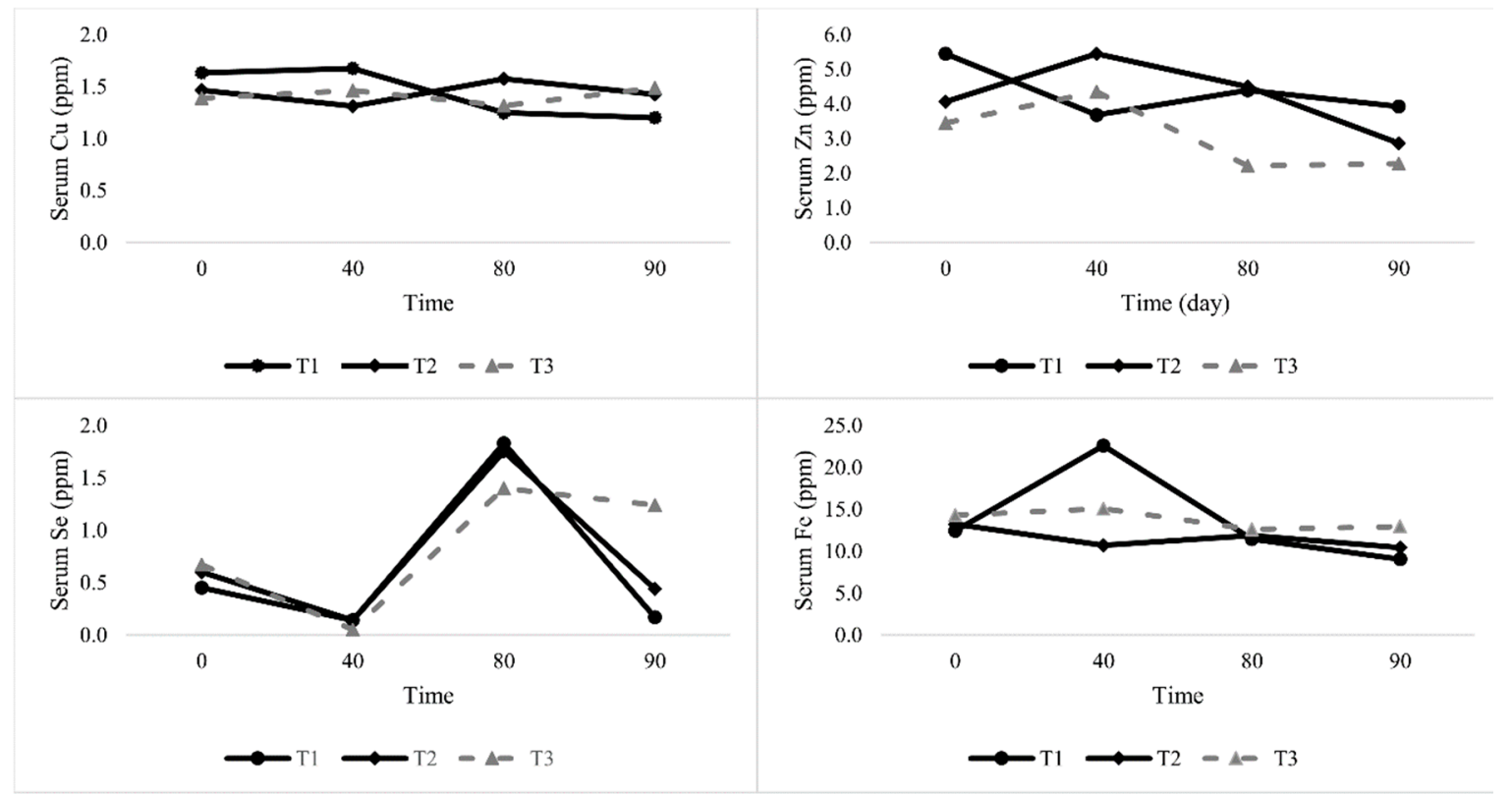

Figure 1. Effect of experimental diets on some mineral levels in the serum (ppm) of lambs at different times. T1: (75.3\% PKC + 0\% corn), T2: (70.3\% PKC + 5\% corn), and T3: $(65.3 \%$ PKC + 10\% corn). $\mathrm{PKC}=$ palm kernel cake.

\section{Discussion}

\subsection{Minerals Balance}

Based on the values obtained in this study, dietary treatments had significant effects on $\mathrm{Cu}, \mathrm{Se}$, $\mathrm{Zn}$, and Fe balance among treatment groups. The feeding of $5 \%$ corn along with $70.3 \%$ PKC or $10 \%$ corn with $65.3 \%$ PKC resulted in higher $\mathrm{Cu}$ intake, apparent absorption, retention, apparent mineral digestibility, and mineral balance compared to no corn diets (T1). The increased consumption of the diets is due to the rise in $\mathrm{Cu}$ intake and this finding is in line with Oladokun et al. [11]. The increase in dietary $\mathrm{Cu}$ caused the groups difference to diminish over time, indicating that any group distinction in the metabolic process is probably saturated with high $\mathrm{Cu}$ intakes [12]. With regards to the $\mathrm{Cu}$ balance, the amount of its excretion in fecal matter was greater than in urine due to the primary route of trace mineral excretion being through the feces [13]. Generally, the quantity of $\mathrm{Cu}$ excreted in the fecal matter of lambs fed on T2 and T3 could transform $\mathrm{Cu}$ into a complex compound of protozoa, resulting in it being excreted less by lambs than lambs not fed the corn diet. Ivan et al. [14] clarified that the increase in $\mathrm{Cu}$ bioavailability due to the elimination of ciliate protozoa from the rumen may amount to between $15 \%$ and 50\%. However, Suttle [15] reported that sulfur could be converted to sulfide by ruminal bacteria and could have a similar adverse effects on the bioavailability of $\mathrm{Cu}$.

In our experiment, the intake, absorption, retention, apparent mineral digestibility, and mineral balance of Se was high in T3, which is a marked diet effect, since the high content of PKC improves the availability of Se $[16,17]$. However, the low absorption of Se in lambs is the result of a reduction of dietary Se to insoluble forms such as elemental Se or hydrogen selenide in the rumen environment [17]. The differences in the absorption among the groups depends on the chemical form of Se and the composition of the diet [16]. The amount of Se did not cause toxicity problems, and the maximum tolerable amount is $5 \mathrm{mg} \mathrm{Se} / \mathrm{kg}$ DM [18]. Most of the inorganic Se is not used immediately in the liver for selenoprotein synthesis and is quickly excreted via the urine [17]. This explains the increase in the level of Se secretion in the urine of lambs in T1.

In the present experiment, $\mathrm{Zn}$ consumption, feces $\mathrm{Zn}$ excretion, apparent absorption, and retention in lambs fed with the corn supplemented diet were lower than that of the control group, but the apparent mineral digestibility of $\mathrm{Zn}(58.31 \%)$ and $\mathrm{Zn}$ balance (60.69\%) was higher due to the increase in fecal 
$\mathrm{Zn}$ excretion and the overall mean of $\mathrm{Zn}$ excretion. However, the high intake of divalent cations such as $\mathrm{Cu}, \mathrm{Fe}$, and $\mathrm{Ca}$ reduced $\mathrm{Zn}$ absorption [18]. The amount of $\mathrm{Zn}$ excreted via urine excretion was similar between lambs fed with corn and those on control diets. The results also show that the urinary excretion of $\mathrm{Zn}$ by lambs were generally higher than $1 \mathrm{mg} / \mathrm{d}$ with no effect on secretion due to its concentration in these diets [18]. It was previously reported that dietary $\mathrm{Zn}$ reduced the accumulation of hepatic $\mathrm{Cu}$ and promotes the formation of relatively non-toxic forms of $\mathrm{Cu}$ in the liver, such as metallothionein, which is involved in the storage and detoxification of $\mathrm{Cu}$ and other heavy metals $[19,20]$. In the present experiment, the supplemented corn diet resulted in relatively low dietary $\mathrm{Zn}$ concentrations. Additionally, it was much less than $1 \mathrm{~g} / \mathrm{kg} \mathrm{DM}$, leading to the lower feed intake and growth of lambs [21,22].

The intake of Fe by lambs fed with the treated diet decreased dramatically. McDowell [23] reported that the massive amount of $\mathrm{Zn}$ and Fe intake could affect $\mathrm{Cu}$ utilization. High dietary $\mathrm{Zn}$ and Fe can reduce $\mathrm{Cu}$ absorption in cattle and sheep $[24,25]$. The primary routes of Fe excretion are via feces and urine [23]. In this study, corn supplementation had an effect on the dietary level of Fe, which altered its absorption amount, resulting in a decrease in its absorbable intake. In any event, the increase in apparent Fe uptake tends to be associated with high Fe retention. It is likely that there exists a mineral binding protein in the PKC diet treated with corn, which is responsible for the decreased absorption of Fe via the process of maintaining its ions in a soluble form during its transfer from the lumen of the intestine into the cell of the intestinal wall. The concentration of Fe in PKC is known to range between 800 and $6000 \mathrm{mg} / \mathrm{kg}$ DM and was $640-1800 \mathrm{mg} / \mathrm{kg}$ DM in this study. The study by Al-Kirshi et al. [26] indicated the probability of using a Fe diet to reduce the bioavailability of dietary $\mathrm{Cu}$ because of the high PKC content.

\subsection{Hematological and Biochemical Parameters}

The average concentrations of hemogram and biochemical indicators in the blood of lambs remained normal at the beginning of the experiment, which is based on average values for RBC concentrations in sheep $\left(8-13\left(\times 10^{6}\right) \mathrm{RBC} / \mathrm{mL}\right)$ [27]. The MCV values of the treatments were within the normal range of 23-48 fl [28]. The variations observed agree with Daramola et al. [29] who reported that age was a practical factor that has a significant effect on the $\mathrm{Hb}$ and RBC of goats, suggesting that the oxygen-carrying capacity of the blood was high in adult goats.

The unchanged PCV, MCV, and MCHC in lambs fed diets with or without corn is supported by the findings of Galıp [30]. The variations in the blood profile occurred as time elapsed, which is due to changes in physiology resulting in the growth of ruminants $[29,31]$ where it was found that the age of farm animals affects their hematological parameters.

The values of WBC, which can be used as an indicator of inflammation, were significantly different among groups. The mean concentration of WBC of the groups remained within the normal range $\left(4000-12,000 \times 10^{9} / \mathrm{L}\right)[27,28]$. The absence of any effect on B Neuts and S Neuts indicated that the source of protein has no effect on the blood profile. The results of this study showed that using PKC as a protein source had no adverse effects on the blood profile and this finding is supported by Nelson and Watkins [32], who indicated that variations in protein sources might not influence the homeostatic mechanism. The lymphocytes, monocytes, and basophils were affected by the treatment, which increased in the group fed on T3. The reason for this is not clear and no corresponding information is available.

The serum ALT, ALP, and AST levels did not indicate significant differences between the treatment means. Total cholesterol levels were significantly different, and there was an increasing trend in T2 and T3, suggesting a dietary influence although the HDL and VLDL in the serum did not register any significant difference among the treatments, while LDL increased significantly in T3. This observation is explained by the fact that the cholesterol content in the serum has been used to assess the changes in lipid metabolism by feeding oil diets. The simultaneous increase in cholesterol and HDL levels in the serum of lambs with a corn-supplemented PKC diet in this study indicates that the inclusion 
was clearly reflected in the serum cholesterol level and that the increased cholesterol was mainly due to the increase in HDL level $[31,33,34]$. The serum level of triglycerides and glucose in lambs fed with corn diets recorded non-significant variations among treatments. In addition, observed blood glucose concentrations were similar to those overseved by Turner et al. [35], although variations in them could be affected by physiological status. In this study, the findings indicate that lambs fed on diets with corn in the PKC were in the normal energy status range. This could be a contributory factor for the lack of differences among treatments, and there were no negative effects on feed intake or the metabolism of the lambs. The serum metabolite values seen in this study were all within the normal range for sheep serum, as reported by Pampori [36]. However, in spite of the higher figures recorded in this study, the corn-fed PKC diets did not have adverse effects on the health conditions of the lambs.

\subsection{Mineral Serum}

This research shows that the dietary inclusion with different corn levels affected the $\mathrm{Cu}, \mathrm{Se}, \mathrm{Zn}$, and Fe content in the blood serum of lambs. It shows that the $\mathrm{Cu}$ concentration in the lambs' serum was below critical levels, indicative of a sufficient dietary treatment. Therefore, the micro minerals' mean value of serum $\mathrm{Cu}$ is similar to the findings of Hidiroglou et al. [37] and Karim and Verma [38]. The average $\mathrm{Cu}$ in the serum from experimental animals was near the reference values. The previous study showed no significant effect of feeding TMR with or without PKC on the $\mathrm{Cu}$ concentration in the serum [4].

However, wide variations have been observed in the Se concentration among lambs fed on T3 and this is generally considered an indicator of body health. This linear relationship between blood Se and Se intake suggests that the former may be an adequate marker for Se status over a range of intakes. Chalabis-Mazurek and Walkuska [39] noticed that Se supplementation distinctly depressed the $\mathrm{Cu}$ and $\mathrm{Fe}$ content in the serum and liver in lambs. Increased feed intake in T3, leading to high concentrations of Se in lambs, seems to be beneficial with respect to its function as an oxidant contained in glutathione peroxidase, an activity that is conditioned by the presence of Se.

Feeding PKC significantly increased $\mathrm{Zn}$ and Fe concentrations in the serum and this finding is in line with Abdelrahman et al. [4]. No difference was seen in lambs receiving the experimental diets (T2 and T3) at day 40 and 80, but for lambs that were fed on T1 for 120 days, serum Zn concentrations increased, while being depressed in the treatment diets. The decline in $\mathrm{Zn}$ levels in T2 and T3 could be due to improvements in the immune body of the lambs fed on T2 and T3. Kargin et al. [40] noted that $\mathrm{Zn}$ is an essential element required for the immunity function to play a role in responding to diseases. Active, synergistic, or antagonistic interrelationships between Fe and other minerals such as $\mathrm{Cu}$ and $\mathrm{Zn}$ have been documented [41-44]. Throughout the experiment, the content of the serum Fe fluctuated, showing an increasing tendency after 10 weeks of the supplementation treatment. However, statistically significant changes were noted in the lamb group that was given $10 \%$ corn supplementation. Accordingly, high intakes of Fe by lambs fed PKC could affect their hormonal activities, and consequently, affect their metabolism and health [4]. This finding could provide a good indicator of the body health of animals. It has been reported that a high level intake of $\mathrm{Cu}, \mathrm{Mg}$, and $\mathrm{Zn}$ contributed to reducing the absorption of Fe [45]. Further, trace minerals like Fe and Mn have also been shown to be Se antagonists [46].

The concentration of all trace minerals reported in this study falls within the normal range, except for Fe values, which were found to be above the normal range in lambs fed with PKC with or without corn. Variations in the mineral composition of PKC among different scientists might be due to the type of soil, water, sampling techniques, and assay procedures [47].

\section{Conclusions}

It is evident from the present study that the inclusion of corn into a PKC urea-treated rice straw-based diet does not have an effect on the hematological and biochemical parameters of lambs after incorporating corn as a source of energy into a PKC-based diet at $5 \%$ and $10 \%$. It could be concluded that the non-significant changes detected in the serum $\mathrm{Cu}$ reflects the health status 
of lambs among groups that related to no difference in liver enzymes. Therefore, these diets could minimize the feed costs and improve the profitability of farming; thus, small ruminant nutrition researchers may benefit by conducting further researches.

Author Contributions: O.A.S., A.R.A. and A.A.S. contributed to original idea and design of the study. O.A.S. and A.Q.S. conducted the experiments and collected the data. H.A. performed statistical analysis. All authors were involved in the manuscript preparation and approved the final manuscript.

Funding: No specific funding for this work.

Acknowledgments: The author Osama Anwer Saeed acknowledges the support of Ministry of higher education and scientific research of Iraq and University Of Anbar for awarding scholarship to pursue his PhD. The authors are grateful to Universiti Putra Malaysia for the use of laboratory facilities.

Conflicts of Interest: The authors declare no conflict of interest.

\section{References}

1. Ben Salem, H.; Nefzaoui, A.; Ben Salem, L. Spineless cactus (Opuntia ficus indica f. inermis) and oldman saltbush (Atriplex nummularia L.) as alternative supplements for growing Barbarine lambs given straw-based diets. Small Rumin. Res. 2004, 51, 65-73. [CrossRef]

2. Zahari, M.W.; Alimon, A. Use of palm kernel cake and oil palm by-products in compound feed. Palm Oil Dev. $2005,40,5-8$.

3. Saeed, O.; Sazili, A.; Akit, H.; Alimon, A.; Mazlan, M.; Samsudin, A. The growth efficiency and carcass characteristics of dorper sheep treated by corn inclusion as energy into palm kernel cake based-diet. Trop. Anim. Sci. J. 2018, 41, 29-36. [CrossRef]

4. Abdelrahman, M.M.; Aljumaah, R.S.; Alyemni, A.H.; Moez, A.; Hassan, M.; Al-Saiady, M. Effect of palm kernel cake and trace minerals on performance of growing Naemi lambs. Res. Opin. Anim. Vet. Sci. 2014, 4 , $268-272$.

5. Sykes, A.; Field, A. Seasonal changes in plasma concentrations of proteins, urea, glucose, calcium and phosphorus in sheep grazing a hill pasture and their relationship to changes in body composition. Agric. Sci. J. 1974, 83, 161-169. [CrossRef]

6. Joshp, P.; Bose, M.; Harish, D. Changes in certain haematological parameters in a siluroid cat fish Clarias batrachus (Linn) exposed to cadmium chloride. Pollut. Res. 2002, 21, 129-131.

7. NRC. Nutrient Requirements of Small Ruminants: Sheep, Goats, Cervids, and New World Camelids; National Academy Press: Washington, DC, USA, 2007.

8. Kaneko, J.J. Carbohydrate metabolism and its diseases. In Clinical Biochemistry of Domestic Animals; Elsevier: Amsterdam, The Netherlands, 1997; pp. 45-81.

9. Kolmer, J.A.; Spaulding, E.H.; Robinson, H.W. Approved laboratory technic. Approv. Lab. Technic. 1951, 52.

10. Wang, W.X.; Fisher, N.S. Assimilation efficiencies of chemical contaminants in aquatic invertebrates: A synthesis. Environ. Toxicol. Chem. 1999, 18, 2034-2045. [CrossRef]

11. Oladokun, A.A.; Wahab, A.; Rahman, N.; Suparjo, M. Prospect of maximising palm kernel cake utilization for livestock and poultry in Malaysia: A review. J. Bio. Agric. Healthc. 2016, 6, 107-113.

12. Knowles, S.; Rounce, J.; Grace, N.; Lee, J. Variation in copper metabolism between two flocks of Romney sheep in response to increasing dietary copper. New Zealand Soc. Anim. Prod Publ. 1998, 58, 195-198.

13. Kwak, W.; Kim, Y.; Choi, D.; Lee, Y. Effect of feeding mixed microbial culture fortified with trace minerals on ruminal fermentation, nutrient digestibility, nitrogen and trace mineral balance in sheep. J. Anim. Sci. Technol. 2016, 58, 21. [CrossRef] [PubMed]

14. Ivan, M.; Veira, D.; Kelleher, C. The alleviation of chronic copper toxicity in sheep by ciliate protozoa. Br. J. Nutr. 1986, 55, 361-367. [CrossRef] [PubMed]

15. Suttle, N.F. Effects of organic and inorganic sulphur on the availability of dietary copper to sheep. Br. J. Nutr. 1974, 32, 559-568. [CrossRef] [PubMed]

16. Koenig, K.; Rode, L.; Cohen, R.; Buckley, W. Effects of diet and chemical form of selenium on selenium metabolism in sheep. J. Anim. Sci. 1997, 75, 817-827. [CrossRef] [PubMed] 
17. Del Razo-Rodriguez, O.; Ramirez-Bribiesca, J.; Lopez-Arellano, R.; Revilla-Vazquez, A.; Gonzalez-Munoz, S.; Cobos-Peralta, M.; Hernandez-Calva, L.; McDowell, L. Effects of dietary level of selenium and grain on digestive metabolism in lambs. Czech. J. Anim. Sci. 2013, 58, 253-261. [CrossRef]

18. NRC. Mineral. Tolerance of Animals: Second Revised Edition 2015; National Academies Press: Washington, WA, USA, 2006.

19. Bremner, I.; Young, B.; Mills, C. Protective effect of zinc supplementation against copper toxicosis in sheep. Br. J. Nutr. 1976, 36, 551-561. [CrossRef]

20. Bremner, I.; Marshall, R. Hepatic copper-and zinc-binding proteins in ruminants: 2. Relationship between $\mathrm{Cu}$ and $\mathrm{Zn}$ concentrations and the occurrence of a metallothionein-like fraction. Br. J. Nutr. 1974, 32, $293-300$. [CrossRef]

21. Ott, E.; Smith, W.; Harrington, R.; Beeson, W. Zinc toxicity in ruminants. I. Effect of high levels of dietary zinc on gains, feed consumption and feed efficiency of lambs. J. Anim. Sci. 1966, 25, 414-418. [CrossRef]

22. Saeed, O.A.; Sazili, A.Q.; Akit, H.; Alimon, A.R.; Samsudin, A.A.B. Effect of corn supplementation on purine derivatives and rumen fermentation in sheep fed PKC and urea-treated rice straw. Trop. Anim. Health Prod. 2018, 50, 1-6. [CrossRef]

23. McDowell, L.R. Minerals in Animal and Human Nutrition; Academic Press Inc.: San Diego, CA, USA, 1992.

24. WHO. Copper Environmental Health Criteria 200, Geneva. Int. Programme Chem. Safety. 1998. Available online: http://www.inchem.org/documents/ehc/ehc/ehc200.htm (accessed on 20 June 2019).

25. Underwood, J.; Suttle, F. The Detection and Correction of Mineral Imbalances; CABI Publishing: New York, NY, USA, 1999.

26. Al-Kirshi, R.; Alimon, A.; Ivan, M. Effects of dietary molybdenum, sulfur and zinc on the excretion and tissue accumulation of trace elements in sheep fed palm kernel cake-based diets. Animal 2011, 5, 1539-1545. [CrossRef] [PubMed]

27. Shek Vugrovečki, A.; Vojta, A.; Šimpraga, M. Establishing reference intervals for haematological and biochemical blood variables in Lika pramenka sheep. Vet. Arh. 2017, 87, 487-499. [CrossRef]

28. Vojta, A.; Shek-Vugrovečki, A.; Radin, L.; Efendić, M.; Pejaković, J.; Šimpraga, M. Hematological and biochemical reference intervals in Dalmatian pramenka sheep estimated from reduced sample size by bootstrap resampling. Vet. Arh. 2011, 81, 25-33.

29. Daramola, J.; Adeloye, A.; Fatoba, T.; Soladoye, A. Haematological and biochemical parameters of West African Dwarf goats. Livest. Res. Rural Dev. 2005, 17, 3. [CrossRef]

30. Galip, N. Effect of supplemental yeast culture and sodium bicarbonate on ruminal fermentation and blood variables in rams. J. Anim. Physiol. Anim. Nutr. 2006, 90, 446-452. [CrossRef]

31. Adeyemi, K.; Sabow, A.; Aghwan, E.M.; Samsudin, A.A.; Alimon, A.R.; Sazili, A.Q. Serum fatty acids, biochemical indices and antioxidant status in goats fed canola oil and palm oil blend. J. Anim. Sci. Tech. 2016, 58, 1-11. [CrossRef]

32. Nelson, A.; Watkins, W. Influence of interval of feeding cottonseed meal to sheep on ration digestibility, nitrogen balance and blood constituents. J. Anim. Sci. 1967, 26, 1175-1178. [CrossRef]

33. Rudel, L.L.; Parks, J.S.; Hedrick, C.C.; Thomas, M.; Williford, K. Lipoprotein and cholesterol metabolism in diet-induced coronary artery atherosclerosis in primates: Role of Cholesterol and Fatty Acids. Prog. Lipid Res. 1998, 37, 353-370. [CrossRef]

34. Choi, S.; Wang, J.; Kim, Y.; Oh, Y.; Song, M. Effect of soybean oil supplementation on the contents of plasma cholesterol and cis9, trans11-CLA of the fat tissues in Sheep. Asian-Australas. J. Anim. Sci. 2006, 19, 679. [CrossRef]

35. Turner, K.; Wildeus, S.; Collins, J. Intake, performance, and blood parameters in young goats offered high forage diets of lespedeza or alfalfa hay. Small Rumin. Res. 2005, 59, 15-23. [CrossRef]

36. Pampori, Z.A. Field cum Laboratory Procedures in Animal Health Care; Daya Publishing House: Delhi, India, 2003.

37. Hidiroglou, M.; Heaney, D.; Hartin, K. Copper poisoning in a flock of sheep. Copper excretion patterns after treatment with molybdenum and sulfur or penicillamine. Can. Vet. J. 1984, 25, 377. [PubMed]

38. Karim, S.; Verma, D. Blood metabolites and circulating mineral profile of lambs maintained under intensive feeding and grazing with supplementation. Indian. J. Small Rumin. 2000, 6, 77-81.

39. Chalabis-Mazurek, A.; Walkuska, G. Effect of different forms of selenium on trace elements in the blood serum and liver tissue of lambs. J. Elem. 2014, 19, 41-53. [CrossRef] 
40. Kargin, F.; Seyrek, K.; Bildik, A.; Aypak, S. Determination of the levels of zinc, copper, calcium, phosphorus and magnesium of Chios ewes in the Aydin Region. Turk. J. Vet. Anim. Sci. 2004, 28, 609-612.

41. Suttle, N.F. Mineral. Nutrition of Livestock; Cabi: London, UK, 2010.

42. Hansen, S.; Schlegel, P.; Legleiter, L.; Lloyd, K.; Spears, J. Bioavailability of copper from copper glycinate in steers fed high dietary sulfur and molybdenum. J. Anim. Sci. 2008, 86, 173-179. [CrossRef] [PubMed]

43. Sousa, I.K.F.d.; Hamad Minervino, A.H.; Sousa, R.d.S.; Chaves, D.F.; Soares, H.S.; Barros, I.d.O.; Araújo, C.A.S.C.d.; Júnior, R.A.B.; Ortolani, E.L. Copper deficiency in sheep with high liver iron accumulation. Vet. Med. Int. 2012. [CrossRef] [PubMed]

44. Saeed, O.A.; Kee, L.T.; Sazili, A.Q.; Akit, H.; Jahromi, M.F.; Alimon, A.R.; Samsudin, A.A. Effects of corn supplementation on the antioxidant activity, selected minerals, and gene expression of selenoprotein and metallothionein in serum, liver, and kidney of sheep-fed palm kernel cake: Urea-treated rice straw diets. 3 Biotech. 2019, 9, 146. [CrossRef] [PubMed]

45. Pirkle, J.L.; Schwartz, J.; Landis, J.R.; Harlan, W.R. The relationship between blood lead levels and blood pressure and its cardiovascular risk implications. Am. J. Epidemiol. 1985, 121, 246-258. [CrossRef] [PubMed]

46. Martin, J.H.; Gordon, R.M.; Fitzwater, S.; Broenkow, W.W. vertex: Phytoplankton/iron studies in the Gulf of Alaska. Deep Sea Res. A. 1989, 36, 649-680. [CrossRef]

47. Shakila, S.; Reddy, P.S. Certain observations on nutritive value of palm kernel meal in comparison to deoiled rice bran. Int. J. Sci. Environ. Technol. 2014, 3, 1071-1075.

(C) 2019 by the authors. Licensee MDPI, Basel, Switzerland. This article is an open access article distributed under the terms and conditions of the Creative Commons Attribution (CC BY) license (http://creativecommons.org/licenses/by/4.0/). 